\title{
Pruritus Uremik
}

\author{
Sudung O. Pardede \\ Departemen Ilmu Kesehatan Anak, Fakultas Kedokteran Universitas Indonesia - RS Dr. Cipto \\ Mangunkusumo Jakarta
}

\begin{abstract}
Pruritus uremik adalah pruritus yang terjadi pada gagal ginjal yang disebabkan oleh toksin uremik, dengan prevalensi berkisar antara 20\%-50\%.. Pruritus uremik dapat mengganggu aktivitas atau pekerjaan, mengganggu tidur, dan menurunkan kualitas hidup. Patogenesis pruritus uremik masih belum jelas, tetapi ada kaitannya dengan hiperparatiroidisme, hormon parathormon, metabolisme kalsium dan fosfor, inervasi kulit abnormal, neuropati somatik, peningkatan kadar histamin, dan reseptor opioid. Faktor neurofisiologik memegang peran penting dalam terjadinya pruritus. Patogenesis yang sering diajukan adalah the immunohypothesis dan hipotesis opioid. Berdasarkan hipotesis ini, berbagai jenis pengobatan dilakukan untuk menanggulangi pruritus uremik.

Meskipun tata laksana pasien penyakit ginjal stadium akhir sudah berkembang pesat, namun tata laksana pruritus masih merupakan masalah klinis. Pengobatan dapat dilakukan secara topikal dengan menggunakan salep seperti capsaicin atau takrolimus. Pengobatan sistemik telah dicoba dengan naltrekson, agonis reseptor $\mu$-opioid, dan nalfurafin, agonis reseptor $\kappa$-opioid. Selain itu perlu diperhatikan terapi suportif lainnya seperti menciptakan suasana yang sejuk. (Sari Pediatri 2010;11(5):348-54).
\end{abstract}

Kata kunci: pruritus, uremik, penyakit ginjal stadium akhir

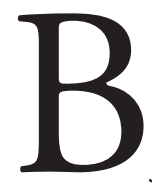

erbagai manifestasi klinis dapat terjadi pada penyakit ginjal stadium akhir (PGSA) seperti nausea, vomitus, lemas, pucat, uremic fetor, edema, pertumbuhan terlambat, osteodistrofi, hipertensi, dan lain-lain. Gejala akibat penurunan fungsi ginjal terjadi secara perlahan-lahan

\section{Alamat korespondensi:}

Dr. Sudung O. Pardede, Sp.A(K). Divisi Nefrologi. Departemen Ilmu Kesehatan Anak Fakultas Kedokteran Universitas Indonesia Jl. Salemba no. 6, Jakarta 10430. Telepon: 021-3915179. Fax.021-390 7743. dan jelas terlihat setelah laju filtrasi glomerulus (LFG) $<10 \mathrm{ml} /$ menit $/ 1,73 \mathrm{~m}^{2}$. Gejala fisik tidak langsung terlihat oleh karena ginjal yang masih baik mempunyai fungsi ginjal cadangan yang besar (reserve fungsional) dan nefron mempunyai kemampuan mengadaptasi kehilangan nefron lainnya. Manifestasi klinis PGSA disebabkan oleh berbagai faktor akibat penurunan fungsi ginjal dan penimbunan sisa metabolisme protein yang disebut toksin uremik. ${ }^{1-4}$ Salah satu gejala yang disebabkan toksin uremik adalah pruritus. Pruritus pada pasien dengan gagal ginjal atau yang sedang menjalani dialisis disebut dengan pruritus uremik. ${ }^{1-7}$ 
Hubungan antara uremia dengan pruritus telah lama diketahui, namun patofisiologi masih belum jelas. Meskipun tata laksana pasien penyakit ginjal stadium akhir (PGSA) sudah berkembang pesat, namun tata laksana pruritus masih menjadi masalah klinis. ${ }^{7-9}$

\section{Penyebab pruritus}

Tidak semua penyebab pruritus diketahui, beberapa keadaan turut berperan, antara lain hiperfosfatemia, hiperparatiroidisme, akumulasi toksin uremik, dan neuropati sensori uremik dini. ${ }^{1-4}$ Pada PGSA, pruritus dapat terjadi oleh berbagai sebab, baik yang ada kaitannya dengan uremia maupun yang tidak berkaitan dengan uremia. Penyebab pruritus pada PGSA antara lain, ${ }^{7}$

1. Keadaan yang berkaitan dengan uremia:

- Pruritus uremik

- Xerosis kulit

- Anemia karena penyakit ginjal kronik

- Hiperparatiroidisme sekunder

2. Keadaan yang tidak berkaitan dengan uremia:

- Hipersensitivitas karena obat

- Penuaan

- Hepatitis

- Diabetes melitus

- Hipotiroidisme

- Anemia defisiensi besi

- Tumor limfoproliferatif

- Hiperkalsemia

\section{Insidens dan faktor risiko pruritus uremik}

Pada awal tahun 1970-an, 65\%-85\% pasien yang menjalani dialisis mengalami pruritus uremik. Awal tahun 1980-an, angka kejadian pruritus uremik menurun hingga 50\%-60\%. Akhir-akhir ini, prevalensi pruritus uremik berkurang menjadi sekitar 20\%-50$\%{ }^{9-10}$ Ke mungkinan disebabkan perbaikan teknik dialisis. Insidens pruritus pada pasien yang menggunakan membran permeabel (polisulfon) lebih rendah dibandingkan dengan pada pasien yang menggunakan membran dialisis yang kurang permeabel (cuprophane). Perbaikan teknis dialisis mengindikasikan terjadi penimbunan pruritogen dengan pemakaian membran yang kurang permeabel. ${ }^{6,9,11,12}$ Berbeda dengan pasien dewasa, pruritus uremik berat sangat jarang ditemukan pada anak yang menjalani dialisis. Dari 199 anak yang menjalani dialisis, hanya $9,1 \%$ mengalami pruritus dan intesitasnya tidak berat. ${ }^{10}$ Faktor risiko terjadinya pruritus antara lain laki-laki, kadar ureum yang tinggi, peningkatan kadar kalsium, fosfor, dan mikroglobulin- $\beta 2 .^{7}$

\section{Toksin uremik}

Salah satu faktor yang berperan pada terjadinya pruritus adalah toksin uremik, yaitu substansia toksik yang berasal dari diet atau substansia endogen yang terjadi karena gagal ginjal. Toksin uremik mempunyai berat molekul 300-2.000 Dalton (mungkin juga hingga 4.000 Dalton) dan terdiri dari berbagai substansia kimiawi heterogen. ${ }^{5}$ Beberapa di antaranya adalah produk flora mikrobiologik dalam usus seperti dan aromatik, indol. ${ }^{1}$ Urea merupakan substansia yang tidak bemuatan (uncharge), tidak terikat dalam plasma, larut dalam air, mudah berdifusi di antara kompartemen air, mudah didialisis, dan tersebar dalam cairan tubuh. Selain toksisitas yang rendah, urea merupakan petanda yang baik pada keadaan uremik karena merupakan degradasi produk protein. Kreatinin tampaknya relatif non toksik. ${ }^{1,5}$

Keadaan uremik ditandai dengan penimbunan toksin uremik yaitu berbagai substansia yang dalam keadaan normal diekskresi atau dimetabolisme oleh ginjal. ${ }^{1,5}$

Toksin uremik dibentuk dari, ${ }^{1,5}$

- Produk metabolik protein dan asam amino

- Urea atau nitrogen ureum darah (blood urea nitrogen), kreatinin, asam urat

- Guanidin (metilgianidin, asam guanidinoasetat, asam guanidinosuksinat)

- Asam oksalat, fenol dan asam phyenolat, indol,

- Furans (asam furan propanoat),

- golongan amin: aliphatic amines (dimetilamin); aromatik (asam hipurat); poliamin (spermin)

- Peptida dan protein: mikroglobulin $\beta-2$

- Produk metabolisme asam nukleat: asam urat, cyclic-AMP, pirimidin

- Elemen inorganik, $\mathrm{H}^{+}, \mathrm{Na}^{+}, \mathrm{Al}^{+}, \mathrm{Mg}_{2}{ }^{+}, \mathrm{K}^{+}$, $\mathrm{Ca}^{+}, \mathrm{PO}_{4}, \mathrm{SO}_{4}$ 
- Mioinositol-2,3-butylene glycol

- Enzim: renin, ribonuklease, lisozim

- Hormon: hormon paratiroid, glukagon, hormon pertumbuhan (growth hormone), kalsitonin, hormon natriuretik

\section{Patogenesis}

Selama duapuluh tahun ini telah dikemukakan berbagai hipotesis patofisiologi pruritus uremik. Konsep yang paling sering dikemukakan adalah peran hormon paratiroid (parathormon=PTH), sebab pruritus uremik lebih berat pada pasien dengan hiperparatiroidisme dan akan menghilang setelah dilakukan paratiroidektomi. Namun demikian, beberapa laporan tidak mendukung teori ini, karena hal yang sama juga terjadi pada presipitasi kristal kalsium fosfat pada peningkatan kadar kalsium dan fosfat serum. ${ }^{2,3.10,13}$ Pada tahun 1968 Massry dkk. ${ }^{14}$ mengajukan teori bahwa patogenesis pruritus uremik berkaitan dengan hiperparatiroidisme, hormon paratiroid hormon, dan metabolisme kalsium dan fosfor. ${ }^{14}$ Meskipun paratiroid hormon bukan zat pruritogenik jika disuntikkan ke kulit, tetapi peningkatan Ca x P akan menyebabkan pruritus. ${ }^{7}$

Berbagai faktor yang berperan dalam terjadinya pruritus uremik seperti inervasi kulit abnormal, neuropati somatik, peningkatan kadar histamin, reseptor opioid, ${ }^{15}$ serta faktor neurofisiologik. ${ }^{2,7,13}$

Sel mast tersebar secara difus di sepanjang kulit dan sebagian besar berdegranulasi. ${ }^{9,16}$ Sel mast pada dermis terletak berdekatan ke saraf aferen $\mathrm{C}$ neuron terminal, dan interaksi antara struktur ini berperan penting dalam mediasi pruritus. ${ }^{7}$ Sel mast akan melepaskan berbagai substansia seperti histamin, protease, interleukin-2, dan tumor necrosis factor. ${ }^{7,16}$ Histamin telah dikenal luas sebagai pruritogenik yang secara langsung menstimulasi neuron terminal oleh reseptor H1. ${ }^{2,7,9,13}$ Jumlah sel mast pada pruritus uremik lebih banyak dibandingkan anak normal dan berkaitan dengan peningkatan kadar hormon paratiroid plasma. Kadar histamin pada pasien pruritus uremik lebih tinggi dibandingkan dengan pada pasien non-pruritus. ${ }^{9}$ Kontroversi tentang sekresi histamin oleh sel mast yang berproliferasi sebagai penyebab pruritus uremik sering muncul. ${ }^{10}$ Terjadinya pruritus disebabkan lepasnya histamin dari sel mast, didukung oleh penelitian tentang fototerapi ultraviolet-B yang dapat menurunkan jumlah sel mast dan memperbaiki pruritus secara bermakna. Tidak ada korelasi antara jumlah sel mast dermis dan kadar histamin serum dengan derajat pruritus pada pasien PGSA. Keadaan inflamasi uremik juga menerangkan tingginya jumlah sel mast di dermis. ${ }^{\text {? }}$

Sitokin pruritogenik dapat diproduksi di kulit oleh berbagai sel teraktivasi yang berdekatan dengan reseptor gatal. Meskipun interleukin-1 bukan pruritogenik, tetapi dapat menyebabkan pelepasan pruritogenik. Pada kulit pasien dialisis terdapat kadar kalsium, magnesium, dan fosfat yang tinggi. Meningkatnya kadar ion divalen dapat menyebabkan presipitasi kalsium atau magnesium fosfat yang menyebabkan pruritus. Magnesium berperan dalam modulasi konduksi saraf serta pelepasan histamin dari sel mast. Kalsium juga berperan pada terjadinya pruritus melalui degranulasi sel mast. Pruritus akan berkurang seiring dengan penurunan kadar kalsium dan magnesium.

Pada uremia, terdapat perubahan ekspresi relatif reseptor $\mu$-opioid dan $\kappa$-opioid pada limfosit. Ketidakseimbangan ekspresi subtipe reseptor opioid berperan dalam patogenesis pruritus uremia. ${ }^{9}$ Substansia P menstimulasi reseptor $\mu$-opioid pada saraf perifer dan otak, dan mengubah keseimbangan antara stimulasi $\mu$-opioid dan $\kappa$-opioid untuk menimbulkan gatal. Efek stimulasi reseptor $\mu$-opioid dan substansia P dihambat

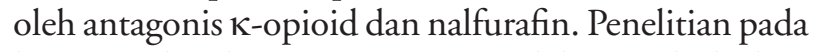
hewan coba dan pasien PGSA telah membuktikan peranan reseptor $\mu$-opioid yang meyakinkan pada pruritus. Satu penelitian melaporkan adanya enolase neuron spesifik intraepidermal-serat saraf immunoreaktif pada pasien uremia, sehingga menimbulkan dugaan terdapat inervasi abnormal yang berkesinambungan sebagai penyebab pruritus pada penyakit PGSA. ${ }^{7}$

Xerosis (kulit kering) sangat sering ditemukan pada pasien PGSA. Meskipun kaitan antara xerosis kulit dengan PGSA tidak konsisten, namun xerosis ditemukan dengan prevalensi yang tinggi pada pasien PGSA usia lanjut. Dengan bukti bahwa substansia tubuh terakumulasi dan uremia merupakan keadaan inflamasi, maka pruritus uremik dianggap sebagai suatu reaksi kulit terhadap proses inflamasi yang masih berlangsung. Faktor lain penyebab pruritus pada pasien PGSA adalah kadar magnesium, aluminium, hipervitaminosis A, dan neuropati perifer. Anemia juga diduga sebagai faktor predisposisi penting meskipun belum ada buktinya. Albumin serum umumnya ditemukan lebih rendah pada pasien dengan pruritus berat dibandingkan dengan tanpa gejala. Laporan yang menyebutkan prevalensi HLAB35 yang tinggi pada pasien PGSA dengan pruritus mengindikasikan adanya predisposisi genetik. ${ }^{7}$ 
Akhir-akhir ini, ada dua konsep yang sering diajukan sebagai patogenesis pruritus uremik.

\section{a. The immuno-hypothesis}

Semakin banyak bukti yang menyebutkan bahwa pruritus uremik lebih disebabkan kelainan sistemik dibandingkan dengan kelainan kulit. Hipotesis imunologi didukung oleh berbagai bukti. Gilchrest GA dkk ${ }^{17}$ pada tahun 1982 melaporkan sejumlah pasien pruritus uremik yang mengalami perbaikan dengan sinar ultraviolet $\mathrm{B}$, meskipun penyinaran hanya dilakukan pada separuh badan. Observasi tersebut membuktikan bahwa radiasi ultraviolet mempunyai efek sistemik. Sinar ultraviolet B terbukti merupakan modulator diferensiasi limfosit Th1 dan Th2 dan mengurangi ekspresi Th $1 .{ }^{17}$ Beberapa penelitian menunjukkan bahwa peningkatan dosis dialisis akan memperbaiki pruritus uremik. Penurunan kejadian pruritus uremik juga dipengaruhi oleh semakin baik modalitas dialisis, seperti meningkatnya penilaian terhadap adekuasi dialisis, efikasi dialisis dengan penggunaan membran dialisis high flux yang terdiri dari fiber sintetik seperti polisulfon atau poliakrilnitrit. ${ }^{9,10}$ Thalidomid dan takrolimus dilaporkan efektif dalam terapi pruritus uremik. Thalidomid (yang digunakan sebagai imunomodulator untuk mengobati reaksi graft-versus-host) menekan produksi TNF- $\alpha$ dan memacu diferensiasi limfosit Th2 dengan supresi sel Th-1 yang memproduksi interleukin-2 (IL-2). Takrolimus mensupresi diferensiasi limfosit Th-1 dan produksi IL-2. Pada umumnya setelah transplantasi ginjal, pasien tidak mengalami pruritus uremik selama mendapat terapi siklosporin meskipun transplan tidak berfungsi lagi. Semua laporan ini menyimpulkan bahwa mekanisme imunologik berperan penting dalam patogenesis pruritus uremik. ${ }^{10}$

Gangguan sistem imun dengan proinflamatori turut berperan dalam patogenesis pruritus uremik, faktor IL-2 yang disekresi oleh limfosit Th-1 teraktivasi turut berperan. Telah dilaporkan bahwa pemberian IL-2 intradermal menimbulkan efek pruritogenik yang cepat tetapi lemah, IL-2 mempunyai kaitan kausal dengan sitokin pruritus uremik dan diferensiasi sel T. Penelitian pendahuluan multisenter menetapkan bahwa diferensiasi Th-1 lebih menonjol pada pruritus uremik dibandingkan dengan tanpa pruritus uremik, yang dibuktikan dengan pengukuran TNF- $\alpha$ intrasitoplasmik dalam sel CD $4 .{ }^{10}$

\section{b. Hipotesis opioid (the opioid hypothesis)}

Konsep patogenetik yang mengubah sistem opiodergik berperan dalam patofisiologi pruritus, pertama kali dilaporkan untuk pruritus kolestatik, didukung oleh beberapa bukti. Pertama, beberapa obat agonisreseptor- $\mu$ dapat menginduksi pruritus. Kedua, pada hewan coba terbukti bahwa kolestasis berhubungan dengan peningkatan tonus opioidergik. Ketiga, pemberian antagonis opiat sangat baik dalam pengobatan pruritus kolestatik. Pruritus kolestatik dapat dimediasi oleh perubahan patologis susunan saraf pusat. Hipotesis didukung oleh temuan yang menyebutkan bahwa global down-regulation reseptor $\mu$ terjadi pada otak tikus dengan kolestatik, pasien dengan kolestatik kronik, dan sindrom opiate withdrawl-like yang dipresipitasi oleh pemberian antagonis opiat oral., ${ }^{9} 10$ Pada tahun 1984, dilaporkan kasus pertama tentang keberhasilan pengobatan pruritus uremik dengan antagonis opiat nalokson secara intravena..$^{18}$ Pemberian antagonis opiat pada pruritus uremik berdasarkan asumsi bahwa peptida opiat endogen berperan dalam patogenesis pruritus uremik. Pemberian naltrekson, antagonis reseptor- $\mu$ menyebabkan keluhan pruritus berkurang secara bermakna, meskipun secara statistik tidak bermakna. Aktivasi ekspresi reseptor- $\kappa$ oleh sel dermal dan limfosit dapat mengurangi pruritus. Dengan demikian, jika reseptor ini tidak distimulasi atau reseptor- $\mu$ overexpressed, maka pasien akan lebih mengeluh pruritus. ${ }^{10}$

Stimuli inflamatori yang disebabkan oleh uremia dan dialisis akan menyebabkan peningkatan diferensiasi limfosit Th1 dan supresi itch-reducing $\kappa$-receptor atau peningkatan $\mu$-receptor di kulit pasien yang menjalani dialisis. Namun hingga saat ini, hipotesis ini belum dapat dibuktikan. Imunomodulator dan obat antagonis reseptor- $\kappa$ telah terbukti sangat membantu pada pruritus yang berat. ${ }^{10}$

Berdasarkan berbagai patogenesis, Keithi-Reddy SR (2007) mengemukakan rangkaian patogenesis pruritus uremik.

- Beberapa substansia menyebabkan lingkungan pruritogenik.

- Pelepasan histamin oleh sel mast sebagai respons terhadap substansia pruritogenik dan menstimulasi C-terminal ujung saraf.

- Terjadi rangkaian sinyal dari ujung saraf yang mengaktivasi area spesifik susunan saraf pusat dan menyebabkan persepsi pruritus. 
- Melalui suatu mekanisme refleks akson langsung, terjadi pelepasan neuropeptida saraf sensorik.

- Pelepasan neuropeptida lokal akan mengagregasi respons pruritus melalui akumulasi stimulasi sel inflamatori dan pengeluaran mediator pruritus. ${ }^{7}$

\section{Manifestasi klinis}

Pruritus uremik sering ditemukan pada PGSA, dapat mengganggu aktivitas atau pekerjaan, mengganggu tidur, dan menurunkan kualitas hidup. Pruritus dapat bersifat menyeluruh atau lokal. ${ }^{7}$ Intensitas dan distribusi pruritus bervariasi dengan derajat keparahan bergantung pada beratnya. Intensitas pruritus mulai dari yang ringan yang timbul sporadik sampai dengan yang berat hingga tidak dapat istirahat baik siang maupun malam hari. ${ }^{10}$

Gejala pertama yang terjadi pada uremia adalah penurunan tenaga dan stamina, nyeri kepala, susah berkonsentrasi, dan malaise. Jika perjalanan penyakit berlangsung lama, dapat terjadi pigmentasi kulit yang diaksentuasi oleh sinar matahari. Pruritus berat menimbulkan ekskoriasi linier yang khas pada kulit yang dapat disertai perdarahan dan infeksi, yang diperberat dengan gangguan fungsi pembekuan dan fungsi imunologis yang terjadi pada uremia. Uremic frost, ditandai dengan adanya kristal urea yang tertinggal setelah berkeringat, umumnya terlihat di area intertriginosa kulit terutama jika pasien jarang mandi. ${ }^{1}$ Garukan berulang akan menimbulkan ekskoriasi, yang dapat menimbulkan kelainan dermatologik, seperti liken simpleks, prurigo modularis, papula keratotik, dan hiperkeratosis folikular. ${ }^{7}$ Pada mulanya pasien dengan pruritus uremik tidak menunjukkan perubahan pada kulit, ekskoriasi akibat garukan dengan atau tanpa impetigo dapat terjadi secara sekunder. Sekitar 25\%$50 \%$ pasien dengan pruritus uremik memperlihatkan pruritus generalisata. Pruritus terutama terjadi di punggung, wajah, dan lengan. Pada 25\% pasien, pruritus lebih berat selama atau segera setelah dialisis. Penelitian membuktikan bahwa beratnya pruritus berkorelasi dengan rendahnya kelangsungan hidup dan dialisis yang adekuat. ${ }^{7}$

\section{Diagnosis}

Istilah pruritus uremik sebenarnya kurang tepat karena pruritus tidak ditemukan pada PGSA dan tidak terdapat pada gagal ginjal akut, tidak berkorelasi dengan beratnya uremia, dan pruritus tidak hilang meskipun dilakukan dialisis, namun demikian istilah ini selalu digunakan. ${ }^{7}$ Diagnosis pruritus uremik ditegakkan berdasarkan kriteria,

- Pruritus timbul segera sebelum onset dialisis, atau pada setiap saat tanpa bukti penyakit aktif yang dapat menyebabkan pruritus.

- Terjadi tiga atau lebih episode pruritus selama periode kurang dari 2 minggu, dengan gejala terjadi beberapa kali sehari, berakhir dalam beberapa menit, dan mengganggu pasien.

- Pruritus terjadi dalam pola teratur selama satu periode enam bulan, tetapi lebih jarang dari keadaan seperti butir $2 .^{7}$

Biopsi kulit pada pruritus uremik tidak dapat memberikan kesimpulan. ${ }^{7}$

\section{Tata laksana}

Pengobatan pruritus uremik sangat sulit meskipun pengobatan dengan obat tertentu kadang-kadang efektif. Sayangnya tidak ada antipruritus yang berspektrum luas, berbagai obat topikal atau sistemik dapat digunakan untuk menekan rasa gatal. ${ }^{1-4,9}$ Beberapa pengobatan telah dicoba seperti eritropoietin, naltrekson, dan pengobatan lain dengan hasil yang baik meskipun sering juga tidak memberikan hasil. Pengobatan pruritus uremik kurang efektif disebabkan patofisiologi pruritus uremik belum jelas. ${ }^{7,10}$

Pasien dengan pruritus umumnya memerlukan suasana sejuk, yang dapat dilakukan dengan 1 . Menggunakan pakaian yang membuat sejuk, 2 . Mempertahankan lingkungan yang tidak terlalu kering, 3. Menggunakan shower atau mandi hangat-hangat kuku, 4. Menghindari alkohol atau makanan/minuman panas atau pedas. Pasien diminta menggunting kuku dan menggaruk dengan perlahan untuk mencegah kerusakan kulit. ${ }^{9}$ Kelainan yang paling sering ditemukan pada pruritus uremik adalah xerosis kulit, sehingga pemberian emolient sangat perlu. ${ }^{9}$ Pemberian emolient seperti gel yang mengandung $80 \%$ air terbukti memberikan hasil yang baik. Penelitian pada duapuluh satu pasien tanpa kontrol, pasien diobati dengan sabun lunak dan emolient moistuirizing minimal dua kali sehari; 16 membaik dan 9 di antaranya mengalami kesembuhan tanpa gejala pruritus. ${ }^{7}$ 
Sinar ultraviolet memberikan hasil yang baik dan aman dalam pengobatan pruritus uremik, telah dilaporkan dalam penelitian uji klinik double blind. Mekanisme efek antipruritus sinar ultraviolet belum diketahui, tetapi diduga terjadi melalui inaktivasi substansia pruritogenik bersirkulasi, pembentukan photoproduct yang mengurangi pruritus, mengubah konten ion divalen dalam kulit, dan menimbulkan degenerasi saraf kulit. ${ }^{19}$ Sinar ultraviolet B menurunkan jumlah sel mast dermal dengan mempercepat apoptosis (kematian sel), menyebabkan degenerasi saraf, dan menurunkan konsentrasi ion divalen kulit. Pada pruritus uremik, sinar ultraviolet B dilaporkan menyebabkan remisi sampai delapan belas bulan. ${ }^{9}$

Faktor lain yang juga berperan dalam terjadinya pruritus adalah disfungsi imun dan perubahan pola produksi limfokin, maka pasien diterapi dengan obat yang mempengaruhi limfosit atau limfokin. Asam amino esensiel seperti asam linoleat- $\gamma$ mengurangi proliferasi limfosit dan produksi limfokin serta mengurangi beratnya pruritus. Penelitian prospektif dengan metode randomized, double blind, placebo controlled, cross over study, krim asam linolenik- $\gamma$ 2,2\% dibandingkan dengan plasebo yang diberikan tiga kali sehari selama dua minggu. Kemudian dilakukan terapi silang untuk masing-masing kelompok. Terlihat efek antipruritus asam linolenat- $\gamma$ yang baik. ${ }^{20}$

Capsaicin, adalah substansia yang diisolasi dari tanaman pepper genus Capsicum, Capsaicin topikal dapat menghilangkan substansia $P$ neuron perifer $C$-fibres dan menghambat konduksi nyeri atau pruritus sehingga mengurangi rasa nyeri dan gatal. ${ }^{9}$ Capsaicin secara bermakna efektif dalam menghilangkan pruritus dan mempunyai efek antipruritus yang lama hingga delapan minggu setelah pengobatan. Krim capsaicin $0,025 \%$ atau $0,075 \%$ dioleskan 3-5 kali sehari. ${ }^{7}$ Beberapa obat yang mengandung anestesi lokal (seperti benzokain, lidokain atau tetrakain/ametokain) dapat digunakan untuk pengobatan pruritus uremik. Strontium nitrat $10-20 \%$ topikal mempunyai efek antipruritus dan efektif dalam mengurangi pruritus. ${ }^{9}$

Salep takrolimus mengurangi gejala klinis pruritus uremik membaik secara dramatis, meskipun beberapa hari setelah salep dihentikan secara perlahan pruritus timbul kembali. Tidak tampak efek samping selama dan setelah pemberian takrolimus. Tampaknya salep takrolimus aman dan cukup efektif sebagai pengobatan jangka pendek terutama pada pruritus berat, namun perlu waspada terhadap efek karsinogenik pada pemakaian jangka lama. Salep takrolimus 0,03\% diberikan 2 kali sehari selama 7 hari. ${ }^{10}$

Ketidakseimbangan stimulasi reseptor $\mu$-opioid dan $\kappa$-opioid berperan dalam patogenesis pruritus, sehingga manipulasi sistem opioid dapat digunakan dalam tata laksana pruritus. Pemberian naltrekson secara sistemik, suatu antagonis reseptor- $\mu$ efektif dalam tata laksana pruritus. Pada penelitian dengan metode placebo-control, double blind crossover pada pasien pruritus uremik persisten yang resisten dengan hemodialisis atau dialisis peritoneal, pemberian naltrekson menyebabkan perbaikan pada $29,2 \%$ pruritus uremik, tetapi tidak terdapat perbedaan bermakna pada kelompok naltrekson dan plasebo. Naltrekson diberikan selama 4 minggu dengan dosis $50 \mathrm{mg} /$ hari. ${ }^{10}$ Kejadian efek samping naltrekson berupa gangguan saluran gastro-intestinal sangat tinggi, yaitu 9 di antara 23 pasien mengalami gangguan gastrointestinal, sehingga obat ini tidak begitu disukai dalam pengobatan pruritus uremik. ${ }^{7}$

Nalfurafin, suatu agonis reseptor $\kappa$-opioid telah dicoba dalam pengobatan pruritus uremik. Pada penelitian metaanalisis, multisenter, randomized, coubleblind, placebo-controlled terhadap pasien yang mengalami pruritus intraktabel, pasien mendapat nalfurafin $5 \mu \mathrm{g}$ atau plasebo secara intravena tiga kali seminggu selama 2-4 minggu. Terlihat efek nalfurafin yang berbeda bermakna dibandingkan dengan plasebo. ${ }^{21}$

Transplantasi ginjal merupakan satu-satunya terapi definitif untuk pruritus uremik refrakter berat pada pasien PGSA, namun hal ini sering tidak mampu laksana dan tidak dapat dilakukan dengan segera. Oleh sebab itu, tata laksana yang dapat dilakukan adalah mengoptimalkan dialisis, pemberian eritropoietin dan suplementasi besi, serta pengobatan hiperparatiroidisme sekunder untuk mempertahankan kadar kalsium dan fosfor dalam keadaan normal. ${ }^{7}$

Keithi-Reddy SR dkk (2007) membuat daftar pilihan terapi pada pasien pruritus uremik: ${ }^{7}$

- Dialisis: transplantasi ginjal, dialisis efisien, eritropoietin

- Terapi topikal: emolient kulit, capsaicin, streoid topikal

- Terapi fisik: fototerapi, akupunktur, sauna

- Terapi sistemik: diet rendah protein, minyak primrose, lidokain dan mexilitin, antagonis opioid, activated charcoal, kolestiramin, antagonis serotonin, paratiroidektomi, thalidomid, nikergolin, nalfurafin 


\section{Kesimpulan}

Pruritus uremik sering ditemukan pada pasien penyakit ginjal stadium akhir (PGSA), dapat mengganggu tidur, aktivitas atau pekerjaan, sehingga menurunkan kualitas hidup. Meskipun tata laksana pruritus uremik sering tidak memuaskan, tetapi beberapa jenis pengobatan memberikan hasil yang baik.

\section{Daftar Pustaka}

1. Depner TA. The uremic syndrome. Dalam: Greenberg A, Cheung AK, Falk RJ, Coffman TM, Jennette JC, penyunting, Primer on kidney diseases. Edisi ke-1, Toronto: National Kidney Foundation, Academic Press; 1994.h.253-8.

2. Lugon JR. Uremic pruritus: a review. Hemodial Int 2005;9:190-8

3. Stahle-Bachkdahl M. Uremic pruritus. Semin Dermatol 1995;14:297-301.

4. Chodorowska G, Wysokinski A, Chodorowski J. Uremic pruritus in chronic renal patients. Ann Univ Mariae Curie Sklodowska, 2004:59;174-9.

5. Kher KK. Chronic renal failure. Dalam: Kher KK, Makker SP, penyunting, Clinical pediatric nephrology. Edisi 1. New York: McGraw-Hill Inc; 1992.h.501-41.

6. Mistik S, Utas S, Ferahbas A, Tokgoz B, Unsal G, Sahan H, Ozturk A, Utas C. An epidemiology study of patients with uremic pruritus. J Eur Acad Dermatol Venereol 2006;20:672-8.

7. Keithi-Reddy SR, Patel TV, Armstrong AW, Singh AK. Uremic pruritus. Kidney Int 2007;72:373-7.

8. Ponticelli C, Bencini PL. Pruritus in dialysis patients: a neglected problem. Nephrol Dial Transplant 1995;12:2174-6

9. Twycross R, Greaves MW, Handwerker H, Jones EA, Libretto SE, Szepietowski JC, dkk. Itch: scratching more than the urface. QJ Med 2003;96:7-26.

10. Mettang T, Pauli-Magnus C, Alscher DM. Uraemic pruritusnew concept and insights from recent trials. Nephrol Dial Transplant 2002;17:1558-63.
11. Zucker I, Yosipovitch G, David M, Gafter U, Boner G. Prevalence and characterization of uremic pruritus in patients undergoing hemodialysis: uremic pruritus is still a major problem for patients with end-stage renal disease. J Am Acad Dermatol 2005;49:842-6.

12. Narita I, Alchi B, Omori K, Sato F, Ajiro J, Saga D, dkk. Etiology and prognostic significance of severe uremic pruritus in chronic hemodialysis patients. Kidney Int 2006;69;1626-7.

13. Urbonas A, Schwartz RA, Szepietowski JC. Uremic pruritus-an update. Am J Nephrol. 2001;21:343-50.

14. Massry SG, Popovtzer MM, Coburn JW. Intractabke pruritus as a manifestation secondary hyperparathyroidisme in uremia. Disapperance of itching after subtotal parathyroidectomi. New Engl J Med 1968;279:697-700.

15. Johansson O, Hilliges M. Stable-Backdahl M. Intraepidermal neuron-specific enclose (NSE)immunoreactive nerve fibres evidence for sprouting in uremic patients on maintenance hemodialysis. Neurosci Lett 1989;99:281-6.

16. Dimkovi N, Djukanovi L, Radmilovi A, Boji P, Juloski T. Uremic pruritus and skin mast cells. Nephron. 1992;61:5-9.

17. Gilchrest GA, Stern RS, Steinman TI, Brown RS, Arndt KA, Anderson WW. Clinical features of pruritus among patients undergoing maintenance hemodialysis. Arch Dermatol 1982;118:154-6.

18. Andersen LW, Friedberg M, Lokkegaard N. Naloxone in treatment of uremic pruritus: a case history. Clin Nephrol 1984;21:355-6.

19. Gilchrest BA, Rowe JW, Brown RS. Relief of uremic pruritus with ultraviolet phototherapy. New Engl J Med 1977;136-8.

20. Chen YC, Chiu WT, Wu MS. Therapeutic effect of of topical gamma-linolenic acid on refractory uremic pruritus. Am J Kidney Dis 2006;48:69-76.

21. Wilkstrom B, Gellert R, Ladefoged SD. Kappa-opioid system in uremic pruritus: multicenter, randomized, double-blind, placebo-controlled, clinical studies. J Am Soc Nephrol 2005;16:3742-7. 